\title{
An Assessment of Changes the Land Use Land Cover and Impact of the It Park at Talwade Pune On the Nearby Villages
}

\author{
Ujjwala Khare, Prajakta Thakur
}

Research Centre and Post Graduate Department of Geography, Nowrosjee Wadia College, Pune, Maharashtra, India

\begin{abstract}
Article Info

Volume 7, Issue 5

Page Number : 172-179

Publication Issue :

September-October-2020

The expansion of urban areas is common in metropolitan cities in India. Pune also has experienced rapid growth in the fringe areas of the city. This is mainly on account of the development of the Information Technology (IT) Parks. These IT Parks have been established in different parts of Pune city. They include Hinjewadi, Kharadi, Talwade and others like the IT parks in Magarpatta area. The IT part at Talwade is located to close to Pune Nashik Highway has had an impact on the villages located around it. The surrounding area includes the villages of Talwade, Chikhli, Nighoje, Mahalunge, Khalumbre and Sudumbre.
\end{abstract}

\section{Article History}

Accepted : 20 Sep 2020

Published : 30 Sep 2020
The changes in the land use that have occurred in areas surrounding Talwade IT parks during the last three decades have been studied by analyzing the LANDSAT images of different time periods. The satellite images of the 1992, 2001 and 2011 were analyzed to detect the temporal changes in the land use and land cover.

This paper attempts to study the changes in land use / land cover which has taken place in these villages in the last two decades. Such a study can be done effectively with the help of remote sensing and GIS techniques. The tertiary sector has experienced a rapid growth especially during the last decade near the IT Park. The occupation structure of these villages is also related to the changes due to the development of the IT Park.

The land use of study area has been analysed using the ground truth applied to the satellite images at decadal interval. Using the digital image processing techniques, the satellite images were then classified and land use / land cover maps were derived. The results show that the area under built-up land has increased by around 14 per cent in the last 20 years. On the contrary, the land under agriculture, barren, pasture has decreased significantly.

Keywords : land use / land cover, remote sensing, GIS, digital image processing. 


\section{INTRODUCTION}

The growth in the IT industry has transformed the areas around the cities like Bangalore, Hyderabad and Pune. In Maharashtra the city of Pune was chosen as an IT hub as it had certain advantages over other regions for setting up technology parks. These include the proximity to Mumbai, presence of prestigious academic institutions and a vast pool of human resources skilled in computer software and engineering. Other factors include the accessibility of the trade centres and the development of tertiary services. Around the major urban centres the physical expansion of the built up areas beyond the municipal boundaries has been very conspicuous. [1]

The IT Park in Pune has other advantages such as the availability of skilled workforce. The MIDC has provided a lot of infrastructural facilities like power, water, electricity, communication facility, hotel, shopping complexes, banks, etc These IT Parks are located in the fringe area due to advantage of lower rent.

Today due to the process of urbanization cities are growing at an alarming rate. Rapid urban development and increasing land use changes due to increasing population and economic growth in selected landscapes is being witnessed of late in India and other developing countries [2].

The continuing liberalization and economic inform programmers is India since 1991 have given an impact to the Indian economy particularly in the Information and Communicators sector. Steps taken by the State to promote this sector includes the establishment of Information Technology Parks in different parts of the country. It is often argued that the process of economic liberalization and associated structural reform would accelerate ruralurban (RU) migration and boost the pace of urbanization. Linking of India with global economy would lead to massive inflow of foreign capital as also rise in indigenous investment resulting in an increase in employment opportunities within or around the existing urban centres [3]. The establishment of the Rajiv Gandhi Info-Tech Park at Hinjewadi and IT Parks in Kharadi and Talwade have resulted in the several changes of the area in the vicinity.

Geographic Information System (GIS) is a system of hardware, software and procedures designed to support the capture, management, manipulation, analysis, modelling and display of spatially referenced data for solving complex planning and management problems [4] The present study aims at studying the changes due to the development process which is associated with the IT Parks. Geoinformatics is today extensively used for managing the rapidly growing information of our cities and villages [5].Remote sensing and GIS can play an imperative role in the study of land use changes [6]. These techniques can be used to understand and interpret the changes in land use in a more efficient manner.

The use of GIS for studying the urban sprawl becomes even more effective with the help of remote sensing. With the availability of multi sensor satellite data at very high spectral, spatial and temporal resolutions, it is now possible to prepare up-to date and accurate land use / land cover maps in less time, at lower cost and with better accuracy [7] 


\section{AIM AND OBJECTIVES:}

The aim of the study is to assess the changes in land use land cover with time in the surrounding part of Talwade IT Park.

To reach the aim following objectives were used:

1. To classify the satellite images (LANDSAT, TM, ETM) for LU/LC and study the temporal changes.

2. To analyze the impact of IT industry on surrounding villages using the socio economic data

\section{STUDY AREA:}

Talwade (18o35'37.02"N, 73o43'46.79" E) is close to Pune so its climatic conditions, Land use pattern are influenced by Pune city. The elevation of Talwade is about 580 mats above mean sea level. This village is situated on north western side of Pune city along the right bank of River Indrayani. The village is located in the north-west outskirts of Pune is within the commuting distance from the heart of the Pune City. Talwade IT Park is close to Pune-Nashik Highway and also closer to Pune-Mumbai Express Highway, and the Mumbai international airport is about $3-3.5$ hours drive.

The study area spread over three taluka namely Haveli Khed and Maval. The villages which were selected were Talwade, Mahalunge, Khalumbre, Sudumbre, Chikhli, and Nighoje.

Pune (18o 32' N 73o 51' E / 18o 53' N, 73o 85' E), the cultural capital of Maharashtra is a rapidly growing urban city. Pune Lies on the leeward side of the Sahyadri ranges also known as the Western Ghats at the confluence of Mula and the Mutha rivers, which are tributaries of the Bhima River. The highest point just outside the urban area is Sinhagarh fort $(1300 \mathrm{~m}$ above msl). The climate of Pune is on the whole dry and invigorating. The cold season from December to February is followed by the hot season lasting up to early June. The period from early June to about the beginning of October is constituted to southwest monsoon. The succeeding period up to November is post-monsoon season. The climate of Pune is pleasant and is an asset to its citizen. Pune experiences four district seasons: summer, monsoon, post- monsoon and winter. Tropical summer months are from March to May; with maximum temperature ranging from $35 \circ \mathrm{o}$ to $38 \mathrm{oC}$.).

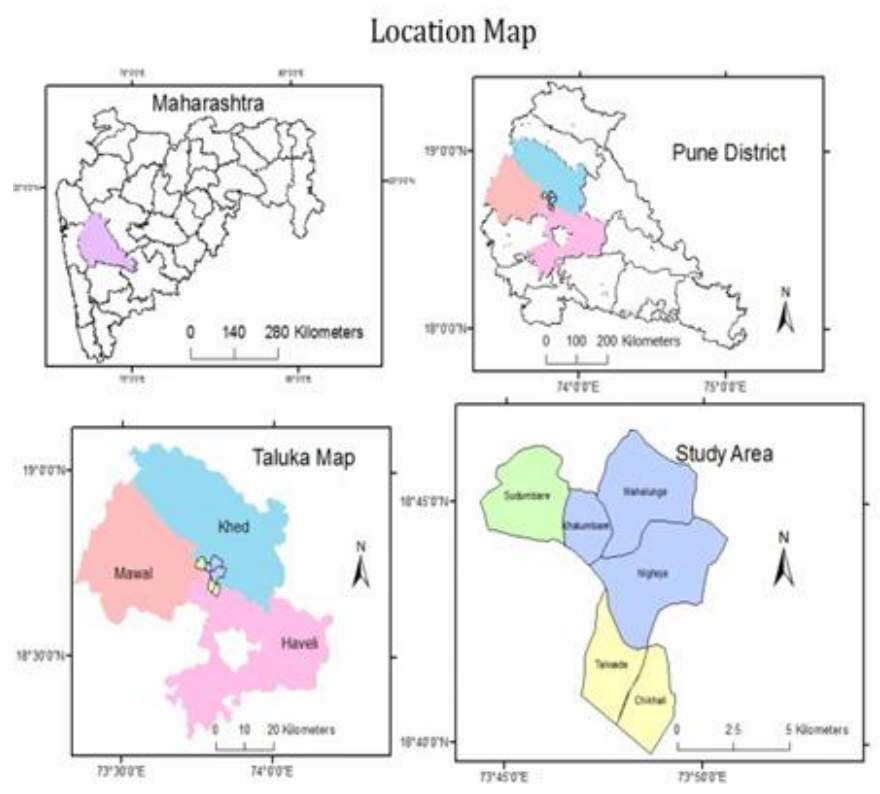

Fig 1 Location map (Source compiled by authors)

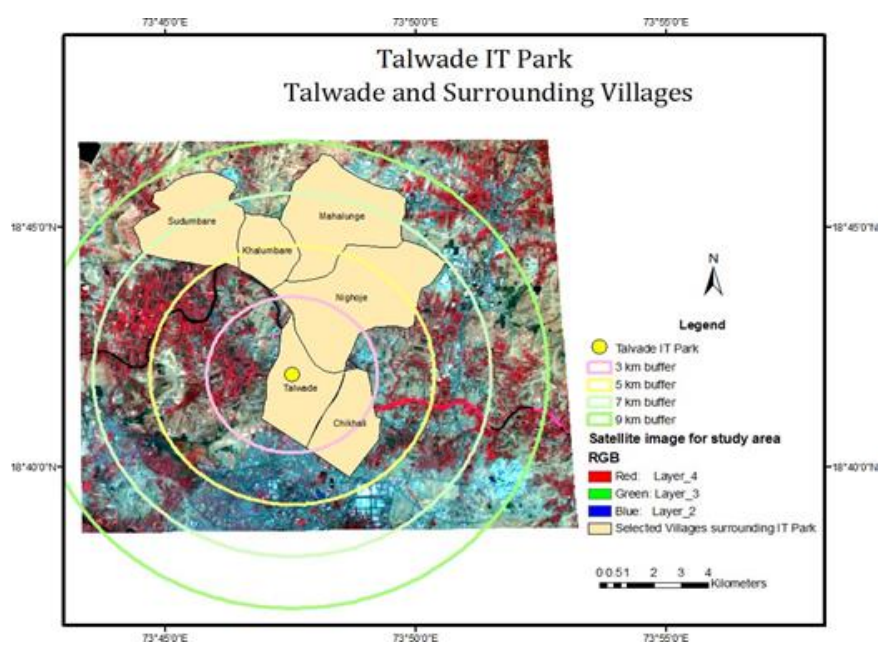

Fig 2 Study area identification (Source compiled by authors) 


\section{DATA AND METHODOLOGY}

The change in land use and land cover for the time period 20 years was analyzed by using satellite images at around10 year interval 1992, 2000 and 2011. The images were downloaded from internet. After scanning topographical map of study area were georeferenced using Arc GIS 9.3 software.

The satellite images after downloading were used to plan the survey in the study area using FCC (false Color Composite) format (Figure 4). The villages in the study area were then surveyed and the ground control points for each class were then used for the generation of the training sites and using those classes, the supervised classification was performed and the classified output was derived (Figure 5).

Table 3.1: satellite details

\begin{tabular}{|l|l|}
\hline Path/ row and date & Satellite data \\
\hline $147 / 47,12-02-1992$ & LANDSAT TM \\
\hline $147 / 47,02-02-2000$ & LANDSAT ETM+ \\
\hline $147 / 47,08-02-2011$ & LANDSAT ETM+ \\
\hline
\end{tabular}

Source: Compiled by authors

Survey for the location was carried out using GPS (Global Positioning System) instrument. The GPS data was then used to identify the survey locations on the Toposheet and Satellite images. The Talwade IT Park was identified as the centre of the study and proximity circles were drawn using the Arc GIS software to identify the nearest villages on the basis of distance from the IT Park. The proximity circles having the distance of 3, 5, 7 and $9 \mathrm{~km}$ were used and the study area was identified for the further analysis (Figure 2). Villages to the west of Talwade are partially occupied by the military cantonment and therefore excluded from the study. To the east of the
Chikhli the area is under the influence of PCMC and therefore not included.

The villages in the study area were surveyed and primary data was collected for six villages with the help of the questionnaire method (20\% sample collected for each village). The data then was compiled, tabulated and analysed for understanding the impact of IT Park and related activities on the socio-economic behaviour of the villagers. Few socioeconomic parameters were selected and data was analysed.

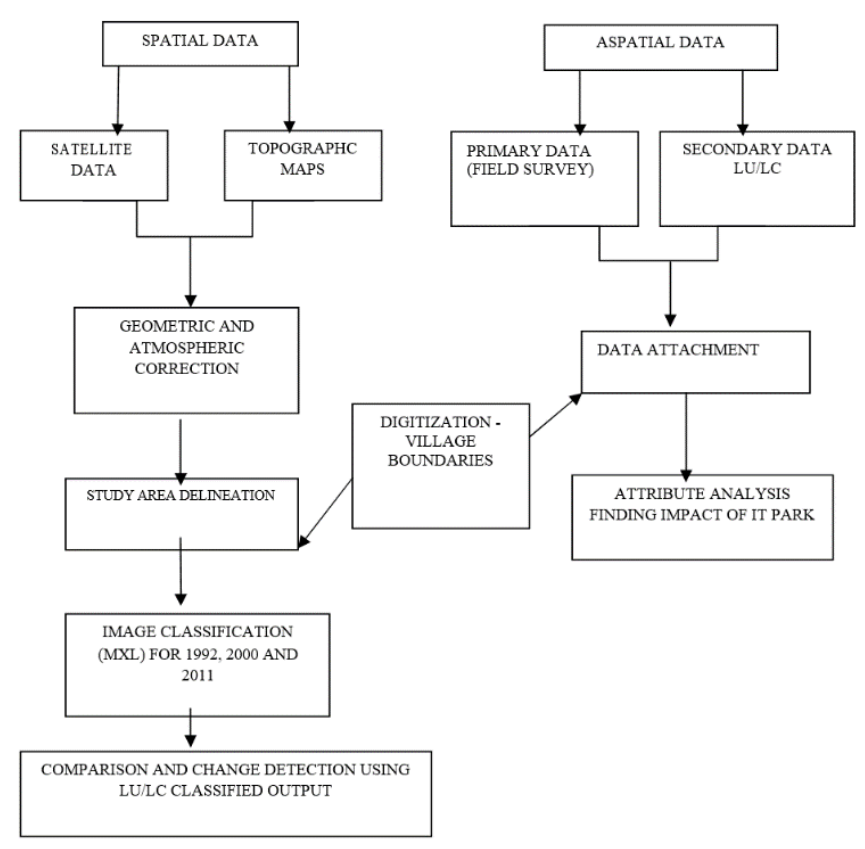

Fig.3 Flowchart explaining Methodology (Source: compiled by authors)

Land- Use/ Land-cover Classification:

Fig 5 Supervised classifications of the study area years 1992, 2000 and 2011 (Source compiled by authors)

It can be observed from figure 5 that land use in Talwade and surrounding village has undergone a significant change within a span of two decades. This may be mainly due to the establishment of IT Park in Talwade. The changes can be mainly observed 
through changes in Built up area, Industrial area and fallow land.

The growth of the IT Park demands an increase in the built up area which is reflected in the category of the Built up area. It can be seen that there is a phenomenal increase in the Built up area and Industrial area which is from $2.28 \%$ to $14.74 \%$ TGA,
$0.008 \%$ to $2.75 \%$ TGA in the time span of two decades (Table 2). The fallow land has declined from $14.06 \%$ to $4.18 \%$ TGA in the last twenty years. Agriculture and fallow together have lost 17 per cent of land (from $47 \%$ to $30 \%$ of TGA in 2011) in 20 years which is now under built up area and industrial land use.

Table 2 Land use/ Land cover with TGA change (\%) of Talwade and surrounding villages

\begin{tabular}{|c|c|c|c|c|c|c|c|c|c|c|}
\hline & & & & & & & \multicolumn{4}{|c|}{ Change } \\
\hline \multicolumn{7}{|c|}{ Area } & \multicolumn{2}{|c|}{$1992-2000$} & \multicolumn{2}{|c|}{$2000-2011$} \\
\hline Classes & 1992 & $\begin{array}{c}\text { TGA } \\
\% \\
1992\end{array}$ & 2000 & $\begin{array}{c}\text { TGA } \\
\% \\
2000\end{array}$ & 2011 & $\begin{array}{c}\text { TGA } \\
\% \\
2011\end{array}$ & Area & TGA $\%$ & Area & $\begin{array}{c}\text { TGA } \\
\%\end{array}$ \\
\hline Water & 41.59 & 0.71 & 34.29 & 0.59 & 35.01 & 0.60 & -7.30 & -0.12 & 0.72 & 0.01 \\
\hline Industrial area & 0.49 & 0.01 & 133.11 & 2.27 & 161.1 & 2.75 & 132.62 & 2.26 & 27.99 & 0.48 \\
\hline Built up area & 133.86 & 2.29 & 432.54 & 7.39 & 863.64 & 14.75 & 298.68 & 5.10 & 431.1 & 7.36 \\
\hline Agriculture Land & 1946.72 & 33.26 & 1461.6 & 24.96 & 1466.28 & 25.04 & -485.12 & -8.30 & 4.68 & 0.08 \\
\hline Pasture Land & 591.89 & 10.11 & 88.29 & 1.51 & 545.13 & 9.31 & $\begin{array}{l}-503.60 \\
\end{array}$ & -8.60 & 456.84 & 7.80 \\
\hline Barren Land & 2315.89 & 39.56 & 2257.2 & 38.54 & 2539.89 & 43.37 & -58.69 & -1.02 & 282.69 & 4.83 \\
\hline Fallow Land & 823.22 & 14.06 & 1449.27 & 24.75 & 245.25 & 4.19 & 626.05 & 10.68 & -1204.02 & -20.56 \\
\hline Total & 5856.30 & 100 & 5856.30 & 100 & 5856.30 & $\overline{100}$ & & & & \\
\hline
\end{tabular}

built up land. Figure 6 shows that built-up land has

TGA-Total Geographic Area; Area in Hectors (Source: Compiled by authors)

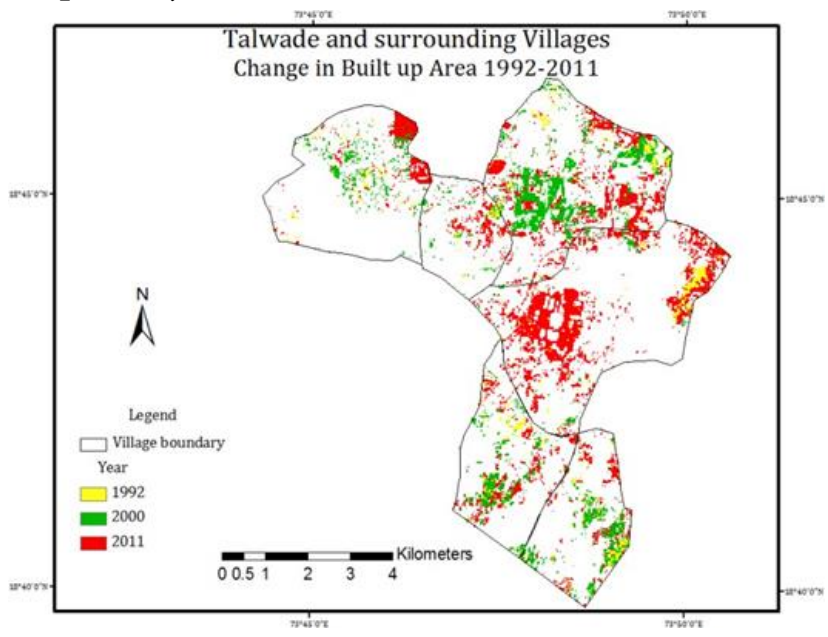

Fig 6 change in Built up area in 1992, 2000 and 2011 (Source Compiled by authors)

During the time span of 20 years, Talwade and surrounding region has shown enormous increase in increased in the central southern and Western parts in 1 st decade (green colour) and overall increase in builtup in last decade (red colour).

\section{Socio economic analysis:}

Using the primary surveyed data, the nature of employment has been taken as one of the socioeconomic parameters for understanding the impact of IT Park on the occupational structure of the selected sample from each village.

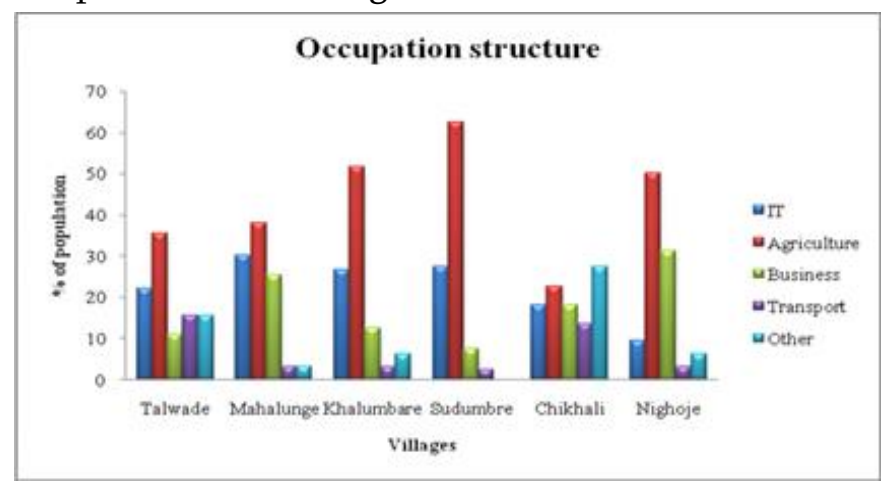

Fig 7 Occupation structure of Talwade and surrounding villages (source Compiled by authors) 
The occupation structure defines the economic activities in the villages, and it has helped to realize the impact Of IT Park and industrial sector on these rural areas.

Talwade village has a lower proportion of persons in the occupation of agriculture. This is probably because a large part of the land in Talwade has been converted into commercial land use within the IT Park. The persons working in the IT sector are not very high and it is similar to the villages of Khalumbre and Sudumbre. However in the transport sector there are higher numbers of persons due to the fact that the requirement of this service is essential in the areas of the IT Park.

In Mahalunge $38 \%$ of the people are engaged in agriculture which is a primary activity. The remaining $62 \%$ people residing in the village are involved in tertiary occupations, 30\% being in IT. 3\% people serve as transport in the area and $26 \%$ people are running private businesses. Rests of the people are working in jobs other than IT sector.

In Khalumbre half of the persons of the representative sample are occupied in agricultural activities. Compared to the other villages of Talwade the persons employed in the IT sector is fairly high.

The percentage share of the persons engaged in the IT sector is similar to that of Sudumbre. But the major share of occupation is found in the agricultural sector which is $62 \%$

Persons engaged in transport related activities and business is very negligible.

In Chikhli $23 \%$ of the people are engaged in agriculture which is a primary activity. The remaining $77 \%$ people residing in the village are involved in tertiary occupations, $18 \%$ being in IT. $14 \%$ people serve as transport in the area and $18 \%$ people are running private businesses. Rest of the people are working in jobs other than IT sector

Nighoje also has more than half of the population engaged in the primary activity of agriculture. It is found that $32 \%$ of their persons have some business in this village which is higher than the other villages around the IT Park.

\subsection{Range of Income Structure}

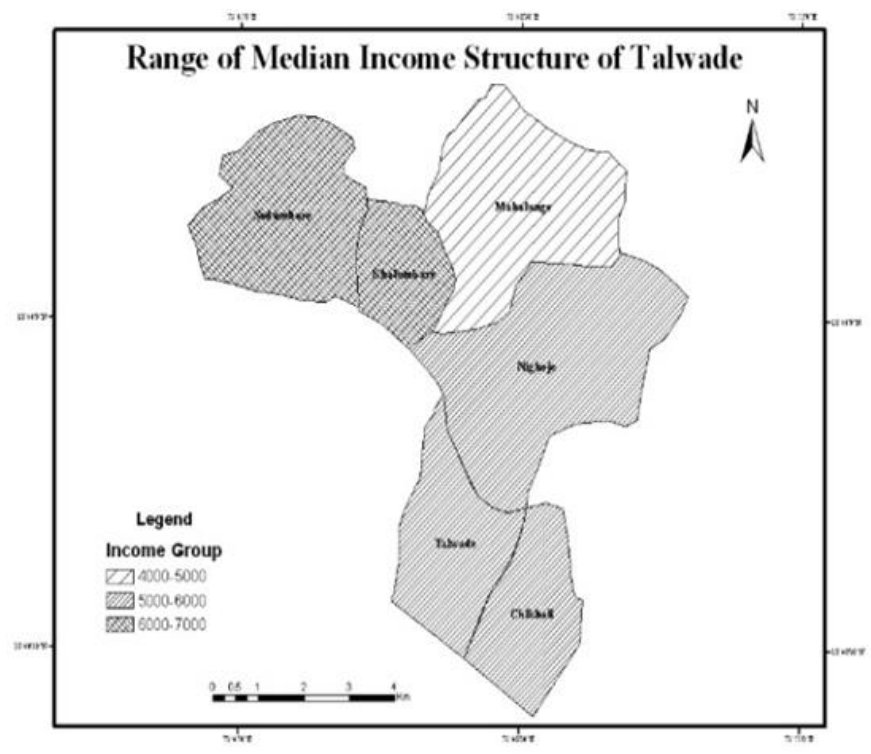

Fig 5 Range of Income Structure (Source Compiled by authors)

These maps represent the range of income structure with respect to the distance from the IT Park. The villages which are adjacent to the villages located near the IT Park have a lower income structure and those further away have a much lower income structure.

The higher incomes close to some villages like Sudumbre and Khalumbre have been a result of the sale of agricultural land. However the income patterns of the villages in the outskirts seem to have no major impact or change on the IT Park 


\section{III.CONCLUSION}

Urban growth remains a major topic concerning GIS and Remote sensing application. RS and GIS have proved to be an effective means for extractive and processing worried resolution of spatial information for monitory urban growth. [8]

1. The land under waste lands (Barren and pasture) as well as arable land (agricultural and fallow) has reduced to their half in the last two decades whereas the industrial and built up land has increased to cover 14 percent of TGA.

2. Considering individual villages, all the villages have shown increase in urban area (industrial + built up) i.e. covering 2 to 14 per cent of the TGA. And similarly there was decrease in the agricultural land by 5 to 20 per cent.

3. Though there is development of IT Park in Talwade, only a few people from the nearby villages benefit from those developments. Only a few persons are engaged with the IT related services. This shows the disparities in the development of the surrounding areas in terms of employment in the IT sectors. There are significant people engaged in agriculture and other activities.

4. The villages like Talwade and Nighoje were purely agriculture in nature. With the advent of the IT Park, the diversity in the occupation was initiated. The infrastructure facilities improved and people began to gain employment in transport, business and other industrial sectors.

5. The higher range of income is reflected in the villages of Khalumbre and Sudumbre due to the sale of the agricultural land for the development of activities related to the needs of the IT parks.
The scope of the study could be enhanced by a detailed study of all the parameters for socio economic conditions of the villages.

\section{REFERENCES}

[1]. Gohad R. N. and Diwan G.R. (2012): Problems and prospects of Pune Metropolitan, 43rd Regional Science Conference Regional, regionalization and planning.

[2]. H.S.Sudhira and T.V.Ramchandra (2007). "Characterising Urban Sprawl from Remote Sensing Data and using Landscape Metrics." In 10th International Conference on Computers in Urban Planning and Urban Management, edited by Cristina Lucas Souza L. de Ant, Rodrigues da Silva. Iguassu Falls, PR, Brazil, 2007.

[3]. Manomani I. K (2010) Assistant Professor Department of geography, MaduraiKamarajUniversity, Maduri. Spatio Temporal Analysis of Land Use in Fringe area using GIS - a case Study of Madurai City, Tamil Nadu. International Journal of Geomatics and Geosciences Volume 1, No 2, 2010.

[4]. K.MadhviLata, Dr.V. Krishna Prasad, Dr. K. V. S. Badarinath, Dr. V. Raghavaswamy. (2007) Measuring urban sprawl: A case study of Hydrabad, National Remote Sensing Agency (NRSA), Department of Space. Government of India, Hyderabad. www.GIS Devlopment.net

[5]. Kundu Amitabh (2001) Trends and Patterns of Urbanization and there economic emplication, India Infrastructure Report 2006 OxfordUniversity press pp-28-40.

[6]. Jensen J R (1990), IntroductoryDigital Image Processing: A Remote Sensing Perspective, Prentice- Hall, New Jersey, 379

[7]. Lakshmi Kantakumar N, Nikhil G Sawant, Shamita Kumar.(2011) Forecasting urban growth based on GIS, RS and SLEUTH model in 
Pune Metropolitan area, International Journal of Geoinfomatics and Geosciences, Volume 2, No 2,

[8]. Desai C G, Patil M B, Mahale V D. and Umrikar B. (2009) Application of remote sensing and geographic Information system to study land use/land cover changes: a case study of Pune Metropolis. Advances in computational Research, ISSN: 0975-3273, Volume 1, Issue 2, pp-10-13.

[9]. Masser (2001) Managing our urban future the roal of RS and GIS, Habitat international Volume 25, pp 39-50.

\section{Cite this article as :}

Ujjwala Khare, Prajakta Thakur, "An Assessment of Changes the Land Use Land Cover and Impact of the It Park at Talwade Pune On the Nearby Villages", International Journal of Scientific Research in Science and Technology (IJSRST), Online ISSN : 2395-602X, Print ISSN : 2395-6011, Volume 7 Issue 5, pp. 172-179, September-October 2020. Available at doi : https://doi.org/10.32628/IJSRST207526

Journal URL : http://ijsrst.com/IJSRST207526 